\title{
Bibliography of the Publications of Moshe Weinfeld (1961-2003)
}

\author{
Prepared by \\ Noam Mizrahi ANd Udi Mizrachi

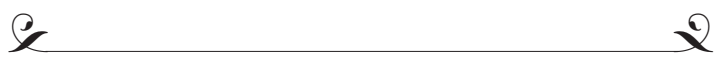

\section{English Publications}

\section{Booklets and Books}

*1. Deuteronomy and the Deuteronomic School. Oxford: Clarendon, 1972. Reprinted, Winona Lake, Ind.: Eisenbrauns, 1992. xvii + 467 pp. [cf. \$3]

*2. "Justice and Righteousness" in Ancient Israel against the Background of Social Reforms in the Ancient Near East. Report No. 4/79. Jerusalem: Institute for Advanced Studies of the Hebrew University, 1979. $25+12$ pp. [cf. ऽ*7]

*3. Getting at the Roots of Wellhausen's Understanding of the Law of Israel: On the 100th Anniversary of the "Prolegomena." Report No. 14/79. Jerusalem: Institute for Advanced Studies of the Hebrew University, 1980. 47 pp. [cf. $\$ 57, \$ 59, \S^{*} 9$ ]

*4. The Organizational Pattern and the Penal Code of the Qumran Sect: A Comparison with Guilds and Religious Associations of the Hellenistic-Roman Period. NTOA 2. Göttingen: Vandenhoeck \& Ruprecht, 1986. 100 pp. [cf. \43]

*5. Deuteronomy 1-11. AB 5. Garden City, N.Y.: Doubleday, 1991. xiv + 458 pp.

*6. The Promise of the Land: The Inheritance of the Land of Canaan by the Israelites. Berkeley: University of California Press, 1993. xxi +327 pp.

*7. Social Justice in Ancient Israel and in the Ancient Near East. Minneapolis: Fortress / Jerusalem: Magnes, 1995. 300 pp. [cf. \$10]

*8. Normative and Sectarian Judaism in the Second Temple Period. Sheffield: Sheffield Academic Press, forthcoming.

Compilers' note: In the cross-references to other versions of a publication in this bibliography, an asterisked reference (e.g., $\mathbb{S}^{*} 1$ ) refers to an item in the English list, while an unmarked reference (e.g., \$1) refers to an item in the Hebrew list. 
*9. The Law and Its Place in Ancient Israel: A Revision of Wellhausen's Prolegomena. VTSup. Leiden: Brill, forthcoming. [cf. \$57, \$59, §*3]

\section{Edited Books}

*10. [with Hayim Tadmor] History, Historiography and Interpretation: Studies in Biblical and Cuneiform Literatures. Jerusalem: Magnes, 1983.

*11. [with Gershon Gallil] Studies in Historical Geography and Biblical Historiography: Presented to Zecharia Kallai. VTSup 81. Leiden: Brill, 2000.

\section{Articles}

*12. The Origin of the Humanism in Deuteronomy. JBL 80/3 (1961) 24147.

*13. Cult Centralization in Israel in the Light of a Neo-Babylonian Analogy. JNES 23/3 (1964) 202-12.

*14. Traces of Assyrian Treaty Formulae in Deuteronomy. Bib 46/4 (1965) 417-27.

*15. Deuteronomy: The Present State of Inquiry. JBL 86/3 (1967) 249-62.

*16. The Period of the Conquest and of the Judges as Seen by the Earlier and Later Sources. VT 17/1 (1967) 93-113. [cf. \$29]

*17. Theological Currents in Pentateuchal Literature. PAAJR 37 (1969) 117-39. [cf. \$30]

*18. The Covenant of Grant in the Old Testament and in the Ancient Near East. JAOS 90/2 (1970) 184-203; “Addenda.” JAOS 92 (1972) 46869.

*19. The Worship of Molech and of the Queen of Heaven and Its Background. UF 4 (1972) 133-54. [see \$*96; cf. \$32]

*20. Covenant Terminology in the Ancient Near East and Its Influence on the West. JAOS 93/2 (1973) 190-99. [cf. \$33]

*21. The Origin of the Apodictic Law: An Overlooked Source. VT 23/1 (1973) 63-75. [cf. \$34]

*22. "Rider of the Clouds" and "Gatherer of the Clouds." JANES 5 (1973) 421-26. [cf. \$56]

*23. La literatura bíblica y el antiguo oriente. Pp. liii-lxx in Sagrade Biblia: Versión crítica sobre los textos Hebreo, Arameo y Griego, ed. F. Cantera Burgos and N. Iglesias Gonzalez. Madrid: Autores Christianos, 1975.

*24. Jeremiah and the Spiritual Metamorphosis of Israel. ZAW 88/1 (1976) 17-56. [cf. \$36]

*25. The Loyalty Oath in the Ancient Near East. UF 8 (1976) 379-414. [cf. $\$ 39]$

*26. Ancient Near Eastern Patterns in Prophetic Literature. VT $27 / 2$ (1977) 178-95. 
*27. Judge and Officer in Ancient Israel and in the Ancient Near East. IOS 7 (1977) 65-88. [cf. \$49]

*28. Gen. 7:11, 8:1-2 against the Background of Ancient Near Eastern Tradition. WO 9/2 (1978) 242-48.

*29. Pentecost as Festival of the Giving of the Law. Immanuel 8 (1978) 7-18.

*30. Literary Creativity. Pp. 27-70, 286-92, 331 in The Age of the Monarchies: Culture and Society, ed. A. Malamat. The World History of the Jewish People. Jerusalem: Massada, 1979. [cf. \$67]

*31. The Royal Guard according to the Temple Scroll. RB 87/3 (1980) 394-96.

*32. Old Testament: The Discipline and Its Goals. Pp. 423-34 in Congress Volume: Vienna 1980, ed. J. A. Emerton. VTSup 32. Leiden: Brill, 1981.

*33. Sabbath, Temple and the Enthronement of the Lord. Pp. 501-12 in Mélanges bibliques et orientaux en l'honeur de M. Henri Cazelles, ed. M. Delcor and A. Caquot. AOAT 212. Neukirchen-Vluyn: Neukirchener Verlag, 1981. [cf. \$47]

*34. The Transition from Tribal Rule to Monarchy and Its Impact on the History of Israel. Pp. 151-66 in Kingship and Consent: The Jewish Political Tradition and Its Contemporary Uses, ed. D. J. Elazer. Ramat Gan: Turtledove, 1981.

*35. A Comparison of a Passage from the Šamaš Hymn (Lines 65-78) with Psalm 107. Pp. 275-79 in 28 Rencontre Assyriologique Internationale in Wien: 6-10 Juli 1981, ed. E. Weidner, H. Hunger, and H. Hirsch. AfO Beiheft 19. Horn: Berger \& Söhne, 1982.

*36. The Counsel of the "Elders" to Rehoboam and Its Implications. Maarav 3/1 (1982) 27-53. Reprinted, pp. 516-39 in Reconsidering Israel and Judah: Recent Studies on the Deuteronomistic History, ed. G. N. Knoppers and J. G. McConville. Sources for Biblical and Theological Studies 8. Winona Lake, Ind.: Eisenbrauns, 2000. [cf. \$35]

*37. Instructions for Temple Visitors in the Bible and in Ancient Egypt. Pp. 224-50 in Egyptological Studies, ed. S. Israelit-Groll. Scripta Hierosolymitana 28. Jerusalem: Magnes, 1982. [cf. \$97]

*38. "Justice and Righteousness" in Ancient Israel against the Background of "Social Reforms" in the Ancient Near East. Pp. 491-519 in vol. 2 of Mesopotamien und Seine Nachbarn: Politische und kulturelle Wechselbeziehungen in alten Vorderasien von 4. bis 1. Jahrtausend v. Chr., ed. H. J. Nissen and J. Renger. Berlin: Reimer, 1982.

*39. The King as the Servant of the People: The Source of the Idea. JJS 33/1-2 (1982) 189-94. [cf. \$58]

*40. Divine Intervention in War in Ancient Israel and in the Ancient Near East. Pp. 121-47 in History, Historiography and Interpretation: Studies in 
Biblical and Cuneiform Literatures, ed. H. Tadmor and M. Weinfeld. Jerusalem: Magnes, 1983. [cf. \$51, \$52]

*41. The Extent of the Promised Land: The Status of Transjordan. Pp. 5975 in Das Land Israel in biblischer Zeit: Jerusalem Symposium 1981 der Hebräischen Universität und der Georg-August-Universität, ed. G. Strecker. Göttingen: Vanderhoeck \& Ruprecht, 1983.

*42. The Heavenly Praise in Unison. Pp. 427-37 in Meqor Hajjim: Festschrift für Georg Mollin zu seinem 75. Geburtstag, ed. I. Seybold. Graz: Akademische druck-u. Verlagsanstalt, 1983.

*43. Social and Cultic Institutions in the Priestly Source against Their Ancient Near Eastern Background. Pp. 95-129 in Proceedings of the Eighth World Congress of Jewish Studies - Panel Sessions: Bible Studies and Hebrew Language. Jerusalem: World Union of Jewish Studies, 1983.

*44. Zion and Jerusalem as Religious and Political Capital: Ideology and Utopia. Pp. 75-115 in The Poet and the Historian: Essays in Literary and Historical Biblical Criticism, ed. R. E. Friedman. HSS 26. Chico, Calif.: Scholar's Press, 1983.

*45. Kuntillet 'Ajrud Inscriptions and Their Significance. Studi epigrafici e linguistici sul Vicino Oriente antico 1 (1984) 121-30. [cf. \$118]

*46. The Emergence of the Deuteronomic Movement: The Historical Antecedents. Pp. 76-98 in Das Deuteronomium: Entstehung, Gestalt und Botschaft, ed. N. Lohfink. Leuven: Leuven University Press, 1985.

*47. Freedom Proclamations in Egypt and in the Ancient Near East. Pp. 317-27 in Pharaonic Egypt: The Bible and Christianity, ed. S. IsraelitGroll. Jerusalem: Magnes, 1985.

*48. Sarah and Abimelech (Genesis 20) against the Background of an Assyrian Law and the Genesis Apocryphon. Pp. 431-36 in Mélanges bibliques et orientaux en l'honneur de M. Mathias Delcor, ed. A. Caquot et al. AOAT 215. Kevelaer: Butzon \& Bercker / Neukirchen-Vluyn: Neukirchener Verlag, 1985. [cf. \$73]

*49. "The Day of the Lord": Aspirations for the Kingdom of God in the Bible and Jewish Liturgy. Pp. 341-72 in Studies in Bible, ed. S. Japhet. Scripta Hierosolymitana 31. Jerusalem: Magnes, 1986. [cf. \$75]

*50. The Protest against Imperialism in Ancient Israelite Prophecy. Pp. 169-82, 510-11 in The Origins and Diversity of Axial Age Civilizations, ed. S. N. Eisenstadt. Albany: State University of New York Press, 1986. [cf. $\$ 100, \S^{*} 52$ ]

*51. Bible Criticism. Pp. 35-40 in Contemporary Jewish Religious Thought, ed. A. A. Cohen and P. Mendes-Flohr. New York: Scribners, 1987.

*52. Der Protest gegen den Imperialismus in der altisraelitischen Prophetie. Pp. 240-57 in vol. 1 of Kulturen der Aschenzeit, ed. S. N. Eisenstadt. Frankfurt: Surkamp, 1987. [cf. \$100, \*50] 
*53. The Tribal League at Sinai. Pp. 303-14 in Ancient Israelite Religion: Essays in Honour of F. M. Cross, ed. P. D. Miller Jr., P. D. Hanson, and S. D. McBride. Philadelphia: Fortress, 1987. [cf. \$80]

*54. Historical Facts behind the Israelite Settlement Pattern. VT 38/3 (1988) 324-32.

*55. Initiation of Political Friendship in Ebla and Its Later Developments. Pp. 345-48 in Wirtschaft und Gesellschaft von Ebla, ed. H. Hauptmann and H. Waetzoldt. HSAO 2. Heidelberg: Orientverlag, 1988.

*56. Job and Its Mesopotamian Parallels: A Typological Analysis. Pp. 217-26 in Text and Context: Old Testament and Semitic Studies for F. C. Fensham, ed. W. Classen. JSOTSup 48. Sheffield: Sheffield Academic Press, 1988.

*57. The Morning Prayers (Birkhoth Hashachar) in Qumran and in the Conventional Jewish Liturgy. RevQ 13/1-4 (1988) 481-94. [cf. \$87]

*58. The Pattern of the Israelite Settlement in Canaan. Pp. 270-83 in Congress Volume: Jerusalem 1986, ed. J. A. Emerton. VTSup 40. Leiden: Brill, 1988. [cf. \$81]

*59. The Promise to the Patriarchs and Its Realization: An Analysis of Foundation Stories. Pp. 353-69 in Society and Economy in the Eastern Mediterranaean c. 1500-1000 B.c., ed. M. Heltzer and E. Lipiński. OLA 23. Leuven: Peeters, 1988.

*60. The Common Heritage of Covenantal Traditions in the Ancient World. Pp. 175-91 in I trattati nel mondo antico forma ideologia funzione, ed. L. Canfora et al. Rome: "L'erma” di Bretschneider, 1989.

*61. The Charge of Hypocrisy in Matthew 23 and in Jewish Sources. Immanuel 24-25 (1990) 52-58.

*62. The Decalogue: Its Significance, Uniqueness, and Place in Israel's Tradition. Pp. 3-47 in Religion and Law: Biblical-Judaic and Islamic Perspectives, ed. E. B. Firmage, B. G. Weiss, and J. W. Welch. Winona Lake: Eisenbrauns, 1990. [cf. \$42]

*63. Sabbatical Year and Jubilee in the Pentateuchal Laws and Their Ancient Near Eastern Background. Pp. 39-62 in The Law in the Bible and Its Environment, ed. T. Veijola. Helsinki: Finnish Exegetical Society / Göttingen: Vandenhoeck \& Ruprecht, 1990.

*64. The Uniqueness of the Decalogue and Its Place in Jewish Tradition. Pp. 1-44 in The Ten Commandments in History and Tradition, ed. B. Z. Segal and G. Levi. Jerusalem: Magnes, 1990. [cf. \$78]

*65. The Census in Mari, in Ancient Israel and in Ancient Rome. Pp. 29398 in Storia e tradizioni di Israele: Scritti in onore di J. Alberto Soggin, ed. D. Garrone and F. Israel. Brescia: Paideia Editrice Brescia, 1991. [cf. \$89] 
*66. God versus Moses in the Temple Scroll: "I Do Not Speak on My Own but on God's Authority" (Sifrei Deut. Sec. 5; John 12,48f.). RevQ 15/12 (1991) 175-80. [cf. \$88]

*67. Semiramis: Her Name and Her Origin. Pp. 99-103 in Ah Assyria . . . : Studies in Assyrian History and Ancient Near Eastern Historiography Presented to Hayim Tadmor, ed. M. Cogan and I. Eph'al. Scripta Hierosolymitana 33. Jerusalem: Magnes, 1991.

*68. What Makes the Ten Commandments Different? BR 7/2 (1991) 35-41.

*69. Grace after Meals in Qumran. JBL 111/3 (1992) 427-40. [cf. \$92]

*70. 'Justice and Righteousness'-משפט וצדקה: The Expression and Its Meaning. Pp. 228-46 in Justice and Righteousness: Biblical Themes and Their Influence, ed. H. G. Reventlow and Y. Hoffman. JSOTSup 137. Sheffield: Sheffield Academic Press, 1992.

*71. The Phases of Human Life in Mesopotamian and Jewish Sources. Pp. 182-89 in Priests, Prophets and Scribes: Essays on the Formation and Heritage of Second Temple Judaism in Honour of Joseph Blenkinsopp, ed. E. Ulrich et al. JSOTSup 149. Sheffield: Sheffield Academic Press, 1992. [cf. $\$ 61]$

*72. Prayer and Liturgical Practice in the Qumran Sect. Pp. 241-58 in The Dead Sea Scrolls: Forty Years of Research, ed. D. Dimant and U. Rappaport. Leiden: Brill / Jerusaelm: Magnes and Yad Izhak Ben-Zvi, 1992. [cf. \$93]

*73. The Ban on the Canaanites in the Biblical Codes and Its Historical Development. Pp. 142-60 in History and Traditions of Early Israel: Studies Presented to Eduard Nielsen, ed. A. Lemaire and B. Otzen. VTSup 50. Leiden: Brill, 1993. [cf. \$84]

*74. Covenant Making in Anatolia and Mesopotamia. JANES 22 (1993) 135-39.

*75. Judges 1.1-2.5: The Conquest under the Leadership of the House of Judah. Pp. 388-400 in Understanding Poets and Prophets: Essays in Honour of George Wishart Anderson, ed. A. G. Auld. JSOTSup 152. Sheffield: Sheffield Academic Press, 1993.

*76. Traces of Hittite Cult in Shiloh, Bethel and in Jerusalem. Pp. 455-72 in Religionsgeschichtliche Beziehungen Zwischen Kleinasien, Nordsyrien und dem Alten Testament: Internationales Symposion, Hamburg, 17-21 Marz 1990, ed. B. Janowski et al. OBO 129. Göttingen: Vandenhoeck \& Ruprecht, 1993. [cf. \$79, \$105]

*77. The Angelic Song over the Luminaries in the Qumran Texts. Pp. 13157 in Time to Prepare the Way in the Wilderness: Papers on the Qumran Scrolls by Fellows of the Institute for Advanced Studies of the Hebrew University, Jerusalem 1989-1990, ed. D. Dimant and L. H. Schiffman. STDJ 16. Leiden: Brill, 1995. 
*78. Deuteronomy's Theological Revolution. BR 12/1 (1996) 38-41, 4445. [cf. \$19]

*79. Feminine Features in the Imagery of God in Israel: The Sacred Marriage and the Sacred Tree. VT 46/4 (1996) 515-29. [cf. \$101]

*80. Introduction. Pp. xvii-xxii in Royal Cities of the Biblical World, ed. J. Goodnick-Westenholz. Jerusalem: Bible Lands Museum, 1996.

*81. The Use of Oil in the Cult of Ancient Israel. Pp. 125-28 in Olive Oil in Antiquity: Israel and Neighbouring Countries from the Neolithic to the Early Arab Period, ed. D. Eitan and M. Heltzer. Padua: Sargon, 1996.

*82. Hillel and the Misunderstanding of Judaism in Modern Scholarship. Pp. 56-70 in Hillel and Jesus: Comparative Studies of Two Major Religious Leaders, ed. J. H. Charlesworth and L. L. Johns. Minneapolis: Fortress, 1997.

*83. Expectations of the Divine Kingdom in Biblical and Postbiblical Literature. Pp. 218-32 in Eschatology in the Bible and in Jewish and Christian Tradition, ed. H. G. Reventlow. JSOTSup 243. Sheffield: Sheffield Academic Press, 1997.

*84. The Jewish Roots of Matthew's Vitriol. BR 13/5 (October 1997) 31.

*85. "Partition, Partition; Wall, Wall, Listen": "Leaking" the Divine Secret to Someone behind the Curtain. AfO 44-45 (1997-98) 222-25. [cf. \$86]

*86. Jerusalem: A Political and Spiritual Capital. Pp. 15-40 in Capital Cities: Urban Planning and Spiritual Dimensions, ed. J. Goodnick-Westenholz. Jerusalem: Bible Lands Museum, 1998.

*87. [with D. R. Seely] 434-438. 4QBarkhi Nafshia ${ }^{\text {a-e }}$ Pp. 255-334 in Qumran Cave 4-XX: Poetical and Liturgical Texts, Part 2, ed. E. Chazon et al. DJD 29. Oxford: Clarendon, 1999.

*87a. [with D. R. Seely] 439. 4QLament by a Leader. Pp. 335-41 in Qumran Cave 4-XX: Poetical and Liturgical Texts, Part 2, ed. E. Chazon et al. DJD 29. Oxford: Clarendon, 1999.

*88. Pelekh in Nehemiah 3. Pp. 249-50 in Studies in Historical Geography and Biblical Historiography: Presented to Zecharia Kallai, ed. G. Gallil and M. Weinfeld. VTSup 81. Leiden: Brill, 2000.

*89. The Roots of the Messianic Idea. Pp. 279-87 in Mythology and Mythologies: Methodological Approaches to Intercultural Influences, ed. R. M. Whiting. Melammu 2. Helsinki: Neo-Assyrian Text Corpus Project, 2001.

*90. The Litany "Our God in Heaven" and Its Precedents in the Dead Sea Scrolls. Pp. 263-69 in Liturgical Perspectives: Prayer and Poetry in Light of the Dead Sea Scrolls, ed. E. G. Chazon. STDJ 48. Leiden: Brill, 2003. [cf. $\$ 107]$ 


\section{Reviews and Replies}

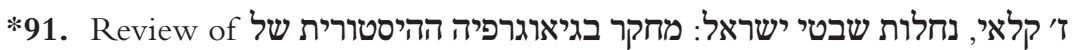

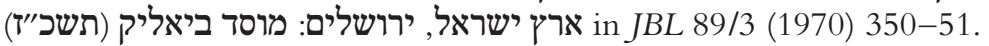

*92. Review of F. Langlamet, Gilgal et les récits de la traversée du Jourdain (Jos. iii-iv). Cahiers de la Revue Biblique 11. Paris: Gabalda, 1969, in IEJ 20/1-2 (1970) 127-28.

*93. Review of J. Milgrom, Studies in Levitical Terminology, vol. 1. Berkeley: University of California Press, 1970, in IEJ 23/1 (1973) 60-62.

*94. “On 'Demythologization and Secularization' in Deuteronomy." Reply to J. Milgrom, "The Alleged 'Demythologization and Secularization' in Deuteronomy." IEJ 23/3 (1973) 156-61, in IEJ 23/4 (1973) 230-33.

*95. "Berit: Covenant vs. Obligation." Review of E. Kutsch, Verheissung und Gesetz: Untersuchungen zum sogenannten 'Bund' im Alten Testament. BZAW 131. Berlin: de Gruyter, 1973, in Bib 56/1 (1975) 120-28.

*96. Review of J. Blenkinsopp, Gibeon and Israel: The Role of Gibeon and the Gibeonites in the Political and Religious History of Early Israel. Cambridge: Cambridge University Press, 1972, in IEJ 26/1 (1976) 60-64.

*97. "Burning Babies in Ancient Israel: A Rejoinder to Morton Smith's Article." Reply to M. Smith, “A Note on Burning Babies." JAOS 95/3 (1975) 477-79, in UF 10 (1978) 411-13. [see §*19]

*98. Review of F. Crüsemann, Der Widerstand gegen das Königtum: Die antiköniglichen Texte des Alten Testamentes und der Kampf am den frühen israelitischen Staat. WMANT 49. Neukirchen-Vluyn: Neukirchener Verlag, 1978, in VT 31/1 (1981) 99-108. [cf. \$117]

*99. Review of B. P. Kittel, The Hymns of Qumran. Chico, Calif.: Scholars Press, 1981, in BO 41 (1984) 712-13.

*100. Review of O. Kaiser (ed.), Staatsverträge. TUAT 1/2: 131-89. Gütersloh: Mohn, 1983, in JAOS 107/2 (1987) 335-36.

*101. Review of G. Langer, Von Gott erwählt: Jerusalem-Die Rezeption von Dtn 12 im frühen Judentum. ÖBS 8. Klosterneuburg: Katholisches Bibelwerk, 1989, in Bib 72/1 (1991) 111-12.

*102. Review of E. W. Nicholson, God and His People: Covenant and Theology in the Old Testament. Oxford: Clarendon, 1986, in RB 98/3 (1991) 431-36. [cf. \$124]

*103. Review of W. W. Hallo, The Book of the People. Atlanta: Scholars Press, 1991, in JSS 40/1 (1995) 105-8.

*104. Review of S. C. Reif, Judaism and Hebrew Prayer: New Perspectives on Jewish Liturgical History. Cambridge: Cambridge University Press, 1993, in VT 48/2 (1998) 282-83. 


\section{Encyclopedia Articles}

Articles in Encyclopedia Judaica. Jerusalem: Keter, 1971.

*105. Chieftain. 5.420-21.

*106. Congregation (Assembly). 5.893-96.

*107. Covenant. 5.1012-22.

*108. Deuteronomy. 5.1573-82.

*109. Elder. 6.578-80.

*110. Josiah. 10.288-93.

*111. Moloch, Cult of. 12.230-33.

*112. Ordeal of Jealousy. 12.1449-50.

*113. Pentateuch. 13.231-61. [cf. \$142]

*114. Presence, Divine. 13.1015-20.

*115. Ruth, Book of. 14.518-22. [cf. \$141]

*116. Tithe. 15.1156-62.

Article in The Interpreter's Dictionary of the Bible: Supplementary Volume. Nashville: Abingdon, 1976.

*117. Covenant, Davidic. Pp. 188-92.

Articles in Theologisches Wörterbuch zum Alten Testament, ed. G. J. Botterweck and H. Ringgren. Stuttgart: Kohlhammer, 1970- (= Theological Dictionary of the Old Testament. Grand Rapids, Mich.: Eerdmans, 1974-).

*118. ברית (=2.253-79).

*119. כבוד (4.23-40 (=7.22-38).

*120. מנחה. 5: Theologie. 4.998-1000 (=8.417-20).

Article in The Encyclopedia of Religion. New York: Macmillan, 1987.

*121. Israelite Religion. 7.481-97. 


\title{
רשימת פרסומים עבריים (תשכ"א-תשס"א)
}

\author{
א. חוברות וספרים \\ 1. ספר דברים ועורכיו, תל אביב: בית הספר הגבוה להשתלמות מורים
}

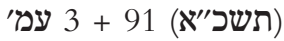

2. עיונים בספרות הדבטרונומיסטית, ירושלים: האוניברסיטה העברית (תשכ״ד)

95

3. מוצא ספר דברים והאסכולה הדבטרונומיסטית (עבודת דוקטור), א-ב,

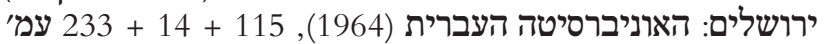

השוו 1 השור

4. עיונים בספרות נביאים ראשונים ובעריכתה, ירושלים: אקדמון (תשכ״ו),

100

5.

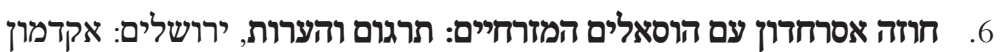

(תשל"ג), 48 עמרון עם

7.

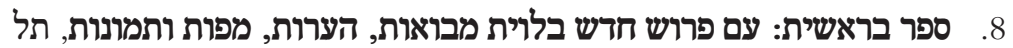

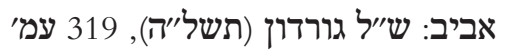

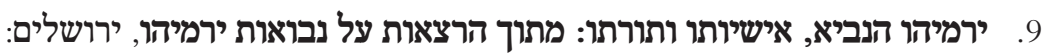

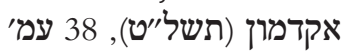

10.

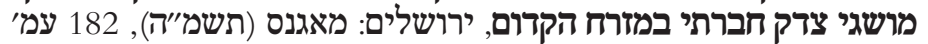

השוו 7* משי 7 מרוק

11. מיהושע עד יאשיהו: תקופות מפנה בתולדות ישראל מההתנחלות ועד חורבן

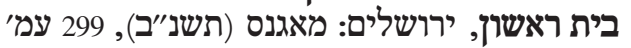

12.

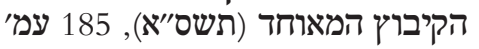

12א. הליטורגיה היהודית הקדומה, ירושלים: מאגנס (בהכנה)

ב. עריכה

13.

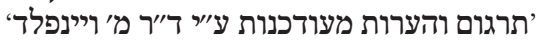

בהפניות לנוסחים אחרים של הפרסומים, הפניה מכוכבת (כגון 1*) מפנה לפוּ לפריט מן

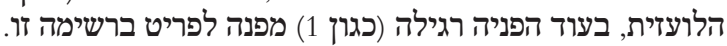


14. שנתון למקרא ולחקר המזרח הקדום, א-יא (תשל"ו-תשנ"ז)

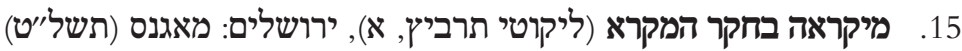

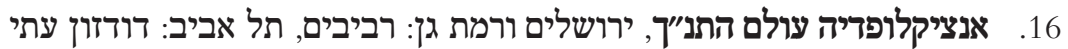

בראשית (תשמ"ב) ויקרא (תשמ"ג) (תשמיר)

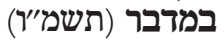

דברים (1994) (1994)

משלי (1996)

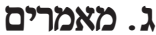

17. זיקתו של ספר דברים לחכמה

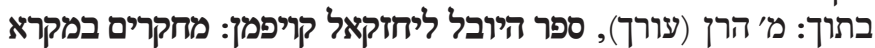

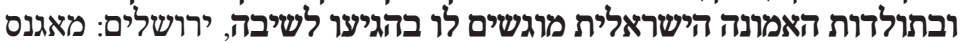

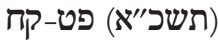

18. . מקורו של רעיון הגמול בספר דברים (ת-8)

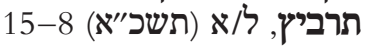

19. המפנה בתפיסת האלהות והפולחן בספר דברים

תרביץ, לא/א (תשכ״יבת) 1-17

השלמות בתוך: מ'ויינפלד (עורך), מיקראה בחקר המקרא (ליקוטי תרביץ, א),

ירושלים: מאגנס (תשל"ט) מינפלד (ערוך) 41

* השוו 78* ה משלים

20. המגמה האוניברסליסטית והמגמה הבדלנית בתקופת שיבת ציון

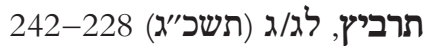

השלמות בתוך: מ' ויינפלד (עורך), מיקראה בחקר המקרא (ליקוטי תרביץ, א),

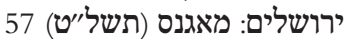

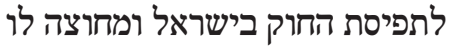

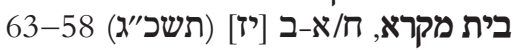

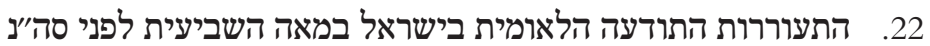

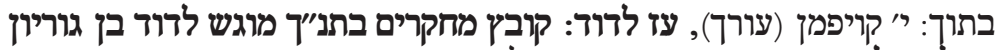

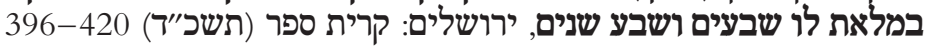

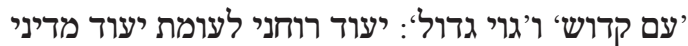

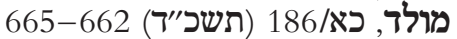

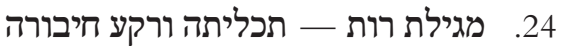

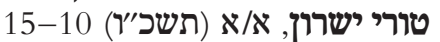

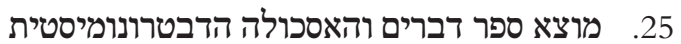

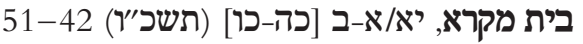
26. כיבוש ארץ כנען והחרמת תושביה - שתי - שתי נקודות ראייה שונות במקרא בית מקרא, יב/ב [ל] (תשכ"ז) 121-127 
27. האל הבורא בבראשית א ובנבואת ישעיהו השני

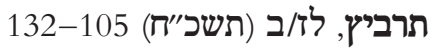

השלמות בתוך: מ'ויינפלד (עורך), מיקראה בחקר המקרא (ליקוטי תרביץ, א),

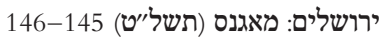

28. חקר המקרא על פרשת דרכים

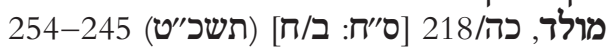

29. תקופת הכיבוש ותקופת השופטים בהיסטוריוגרפיה הישראלית הקדומה

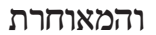

בתוך: ש'אברמסקי ואחרים (עורכים), ספר שמואל ייבין: מחקרים ארכיאולוגיה, לשון ותולדות ישראל, ירושלים: ספרים החברה לחקר המקראי מחרים בישראל וקרית ספר (תש״ולי) 187-205

* השוו 16 בישרו

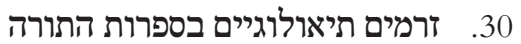

בית מקרא, טז/א [מד] (תשל בסרא) 10-22

השוו 17* ביות

ירמיהו, אישיותו ותורתו

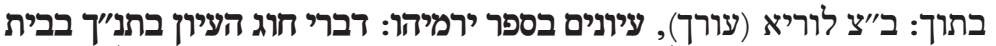

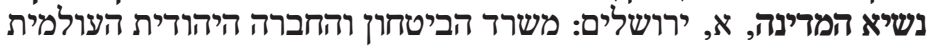
לתנ״ך (תשל"א)

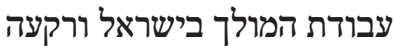
דברי הקונגרס היהודי בישרי העולמי החמישי למדעי היהותי המדות, א, ירושלים: האיגוד העולמי למדעי היהדות (תשכ״ העיט) 37-61, 152 השוו הערו

'הברית והחסד' - המונחים וגלגולי התפתחותם בישראל ובעולם העתיק לשוננו, לו/ב-ג (תשל ריבר) 85-105

השוו 20*; ראו לרונרות 113

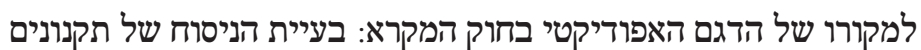

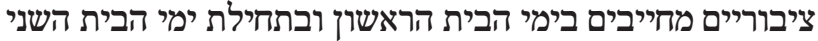
תרביץ, מא/ד (תשל"ב) 349-360 *21 השור

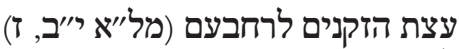
.35

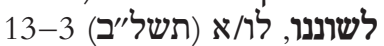

*36 השוו 36

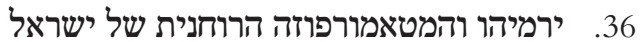

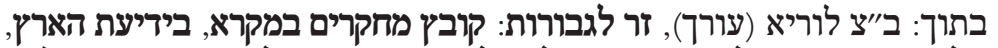

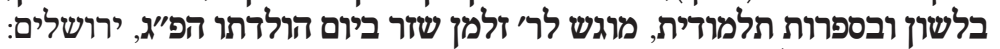


37. המעשר במקרא - רקלו הממלכתי והפולחני

באר שבע, א (תשל"ג) 122-131

38.

הספרות השומרית וספר תהילים - מבוף - מבוא למחקר השואתי

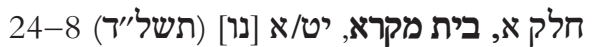

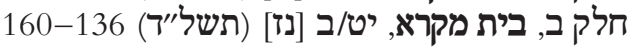

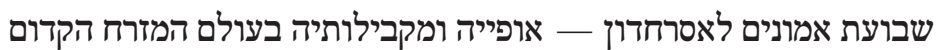

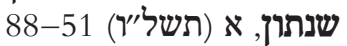

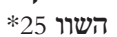

40. השבעת הווסאלים של אסרחדון מלך אשור: תרגום והערות

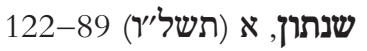

41. עקבות של קדושת יוצר ופסוקי דזמרה במגילות קומראן ובספר בן סירא

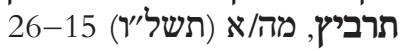

42. עשרת הדיברות: משמעותם וגלגולם במסורת (תמורת ישראל

הגות במקרא, ב (1976) 109-121

*62 6שות

43. דפוסים ארגוניים ותקנות עונשים במגילת סרך היחד

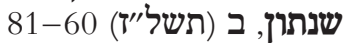

השוו 4 שנרו

המתת עובר - עמדתה של מסורת ישראל בהשוואה לעמדת עמים אחרים

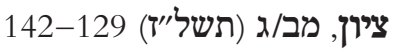

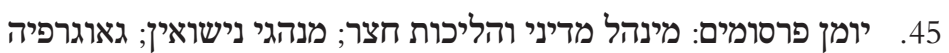

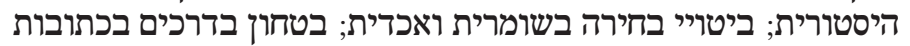
מלכותיות משורית

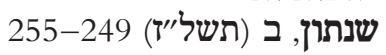

46. המקרא ועולמו - בעליית הדיון בדיסציפלינה (הרצאה בכנס ביום 29.3.1977)

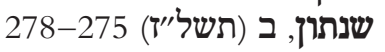

47. שבת ומקדש והמלכת ה': לבעיית בית בית היוצר של בראשית א,א-ב,ג

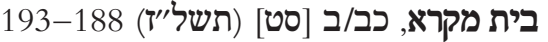

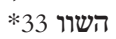

48. ה'שוטר', משמעו ותפקידיו

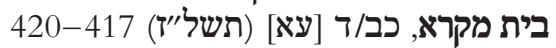

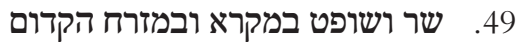

דברי הקונגרס העולמי השישי למדירום למירי היהדות, א, ירושלים: האיגוד העולמי

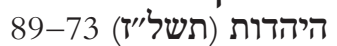

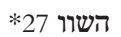
50. תהלה לשמש שנתון, ב (תשל"ז) 239-248 
51. מלחמתו של האל בישראל ובמזרח הקדמון

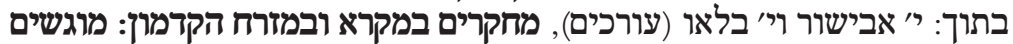
לשמואל א׳ ליונשטם במלאת לו שבעים שנה, ירושלים: א׳ רובינשטין הקדין

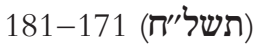

השוו 40 השר

52. 'מן השמים נלחמו': התערבות גופים שמימיים בקרב עם האויב בישראל

ובמזרח הקדמון

ארץ ישראל, יד (תשל"ח) 23-30

השוו 40* ישרו

הבקשות לדעת, תשובה וסליחה בתפילת שמונה עשרה: אופיין של הבקשות,

מקבילותיהן בקומראן ושרשיהן במסליה במקרא בתפילת

תרביץ, מח/ג (תשל ביט) 186-200

ראו 121

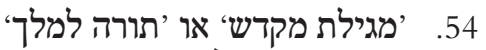

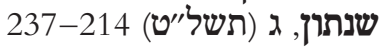

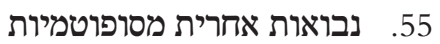

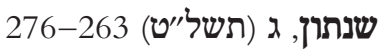

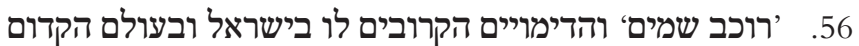

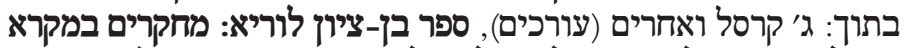

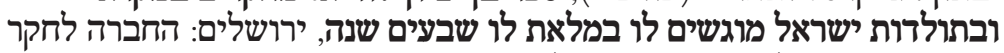

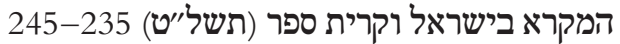

השוו 21* הירור

57. לשרשי משנתו של יוליוס ולהארזן

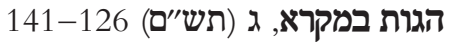

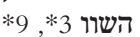

המלך כעבד העם - למקורו של הרעיון

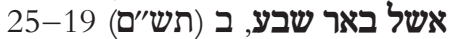

*39 השוו 39

משנתו של יוליוס ולהארזן: הערכה חדשה במלאת מאה שנה להופעת חיבורו

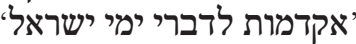

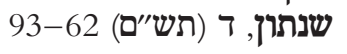

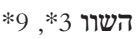

60. תיאולוגיה וחכמה במסורת המסופוטאמית מהאלף השלישי לפנה״ס בזיקתה למקרא תיאוריה

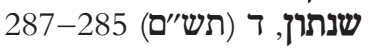

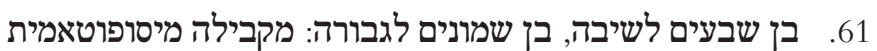

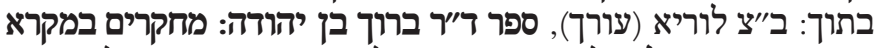

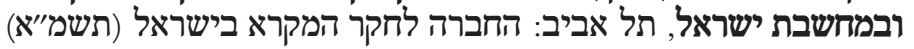


62. המושג יום ה' בנבואה ובעית בית היוצר שלו

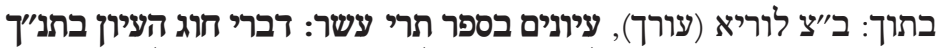

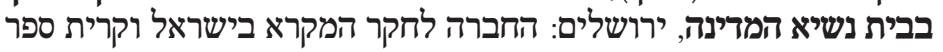

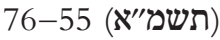

63. יומן פרסומים: א. הפרימאט המוסרי בנבואות המזרח הקדמון; ב. דינים

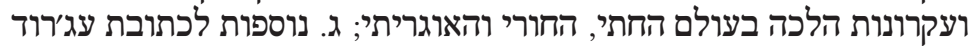

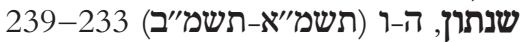
64. נבואת בלעם בכתובת מדיר עלא (סוכות) (ספות)

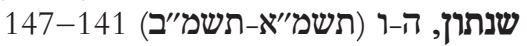

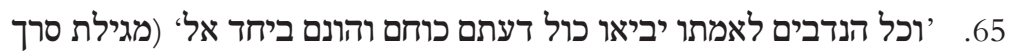

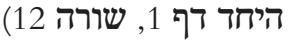
בתוך: ב'אופנהיימר (עורך), עיונים במקרא: ספר זכרון ליהושע מאיר גרינץ

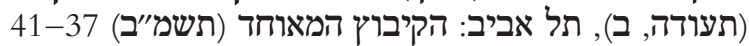

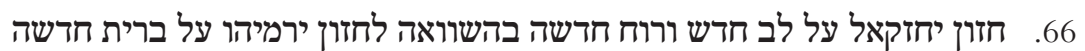

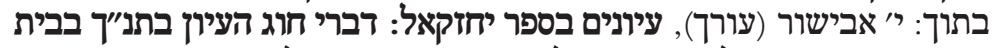
נשיא המדינה, ירושלים: החברה לחקר המקרא בישראל וברי וקרית ספר (תשמון בעיב) 308-285

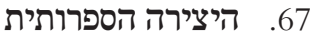
בתוך: א' מלמט (עורך), ימי המלוכה - תרבות - תובית וחברה (ההיסטוריה של עם ישראל, ה), תל אביב: עם עובד (תשמ״בי) 22-53, 210-215, 249 השוו 30 הלית לגלגוליה של משאלה בישראל ובעמים: 'ומצא חן ושכל טוב בעיני אלהים

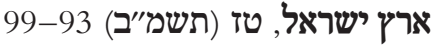

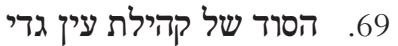

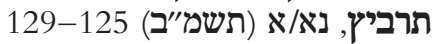
70. בתוך: מ'בר אשר ואחרים (עורכים), מחקרים לשיל לשון: מוגשים לזאב בן חיים

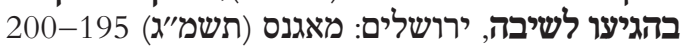

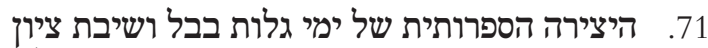

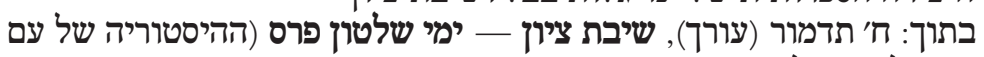

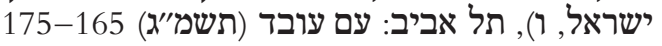

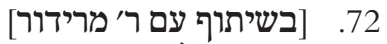

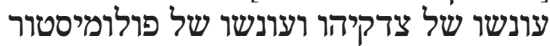

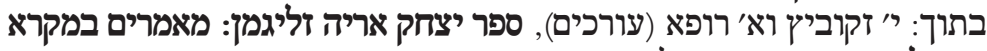

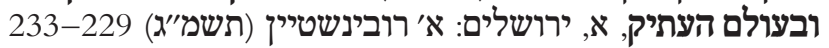

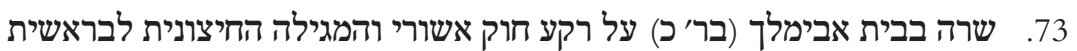

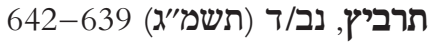


74. ירושת הארץ - זכות וחובה: תפיסת ההבטחה במקורות מימי בית ראשון וימי

בית שני

$$
\text { ציון, מט/ב (תשמ"ד) 115-137 שית }
$$

75. הציפייה למלכות אלהים במקרא והשתקפותה בליטורגיה היהודית: למהותו

של רעיון 'יום ה'יפלי בתוך: צ׳ ברס (עורך), משיחיות 'יום ואסכטולוגיה: קובץ מאמרים, ירושלים: מרכז

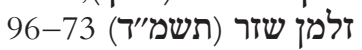
* השוו 49

76. הטקסט הארמי (בכתב דמוטי) ממצרים על מוסר ופולחן ויחסו למקרא

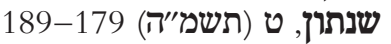
77.

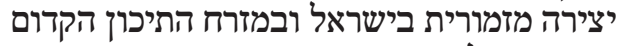
ארץ ישראל, יח (תשמ"ה) 130-140 בישראל ובמזרח

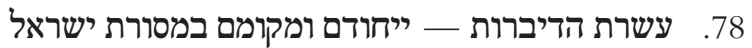

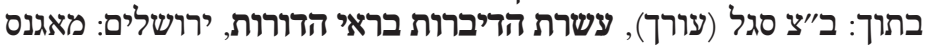

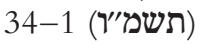
*64

79. עקבות הווי חתי בנוהג פולחני-טכסי בישראל העתיקה

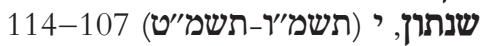
השוו 76* , שנתור 80.

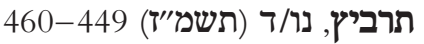

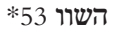

81. מסורת ההתנחלות של שבטי ישראל בכנעץ: הדגם ואופיו

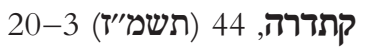
השוו 58* התרורה

82. פרשנות המקרא בדור התחייה בישראל משרים

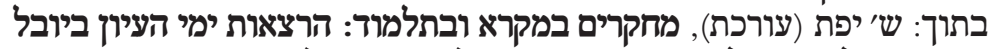

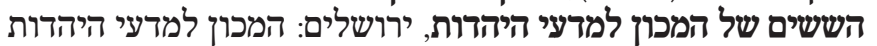
באוניברסיטה העברית (תשמ"ז) 9-15 83. בתוך: ז' פלק (עורך), גבורות הרמח, ירושל משלים: מישרים והחברה לחקר המקרא בישראל (תשמ"ז) רתוך (ערך), 84. גירוש, הורשה והחרמה של האוכלוסייה הקדם ישראלית בחוקי המקרא

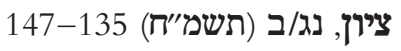
השוו 73* 85. קתדרה, 47 (תשמ"ה) 3-16-12 המובחת 
86. 'מחיצה, מחיצה; קיר, קיר שמעני' - 'הדלפת' סוד האל אל מאחורי הפרגוד

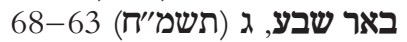

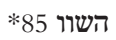
ברכות השחר במגילות קומראן ובתפילה היהודית המקובלת סיני, נג/קה (תשרי חשון תשי"ן) עב פב וכרילה

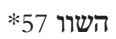
'לא מעצמי אני אומר לכם אלא מפי הקדש אני אומר לכם' (ספרי דברים

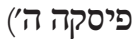

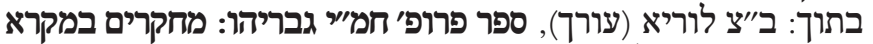
ובמחשבת ישראל, ב, ירושלים: החברה לחקר המקרא בישראל מחקרים (תשנ״אואי 64-63

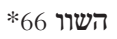
ה'מיפקד' במארי, בישראל וברומא העתיקה (תשני

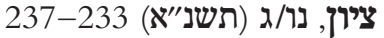
*6שוו מעדה למלכות

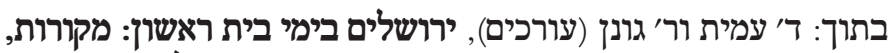
סיכומים, פרשיות נבחרות וחומר עזר (עידן, 15), ירושלים: יד יצחים יצחק בן צבי ביותי

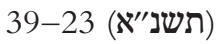
91

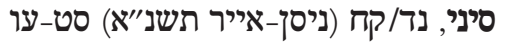

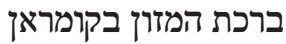
תרביץ, סא/א (תשנ״ב) 15-23 בקוץ ביכון

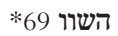
הליטורגיה בקומראן בתוך: מ' ברושי ואחרים מרוץ (עורכים), מגילות מדבר יהודה: ארבעים שנות

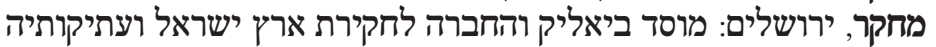

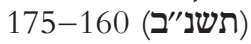
השוו 72* תשנ"

מפעלו של משה שור בחקר המשפט הבבלי

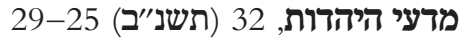

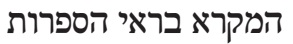

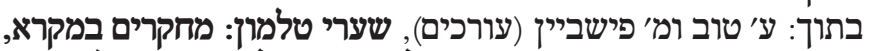

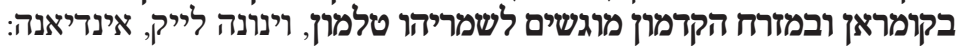

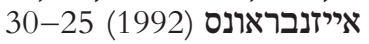
96. הנסיבות ההיסטוריות של הולדת הדת המונותאיסטית - המסורות על משה

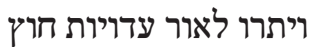
בתוך: לזכרו של פרופ'ש. א. ליונשטם, ירושלים: אקדמון (תשנ״ב) 19-28 
97. הוראות למבקרי המקדש במקרא ובמצרים הקדומה

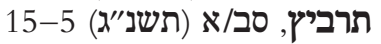

השוו 37* המרביק

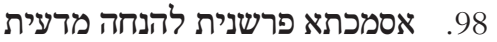

בתוך: ש׳ יפת (עורכת), המקרא בראי מפרשיו: ספר זיכרון לשרה קמין,

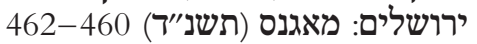

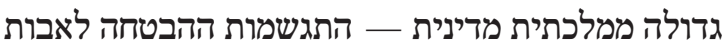

ארץ ישראל, כד (תשנ"ד) 87-92 מרולת מרית

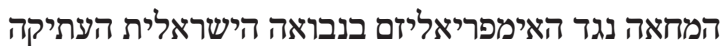

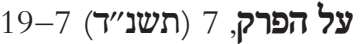

השוו 50*

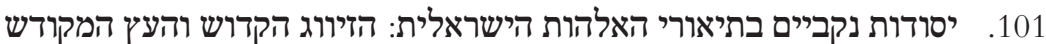

בית מקרא, מקביד בתמג] (תשנ"ה) 348-358

השוו 79* שליר

מקורה המקראי של תפילת העמידה בשבת ומועד

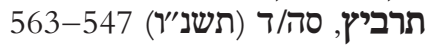

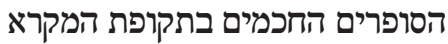

.103

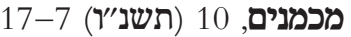

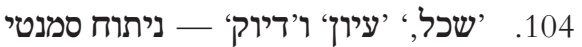

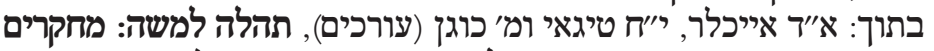

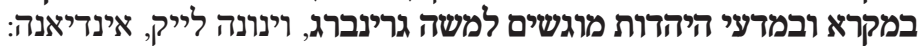

אייזנבראונס (תשנ״ז) 101-105

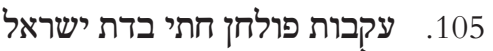

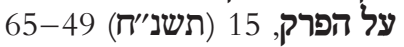

השוו 76* 79 הפרק,

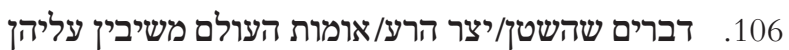

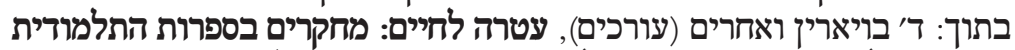

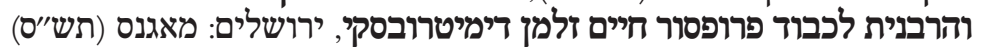

הליטניה 'אלוהינו בשמים' ועקבותיה במגילות קומראן

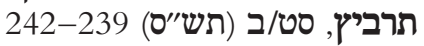

108. משמעה של "ברית ידידות" פוליטית בישראל ובמזרח הקדום

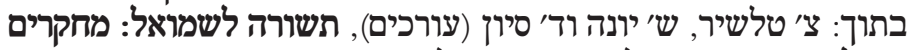
בעולם המקרא, ירושלים: מוסד ביאליק (תשס"א) 178-183

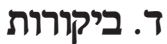

O. Bächli, Israel und die Völker Eine Studie zum ביקורת על]

[Deuteronomium, Zürich: Zwingli (1962)

קרית ספר, לח/ג (תשכ"ג) 329-330 
משנתו המקראית של יחזקאל קויפמן .110

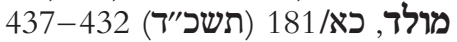

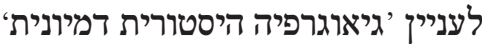

[תגובה ליי'מ גרינץ, 'גיאוגרפיה היסטרורית דמיונית,' בית מקרא, טז/ב [מה]

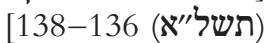

בית מקרא, יז/א [מח] (תשל"ב) 115

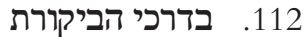

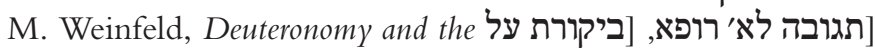

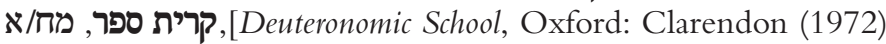

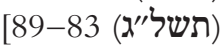

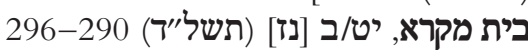

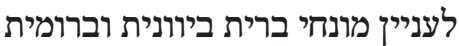
.113

[תגובה לב' ליפשיץ, 'על מונחים "מקבילים" ומוצאם המשותף', לשוננו,

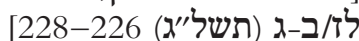

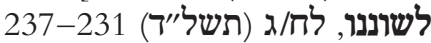

ראו 33

114. תגובות למאמרים

[ביקורת על רוב המאמרים שנתפרסמו בכרך הנ״"ל]

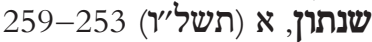

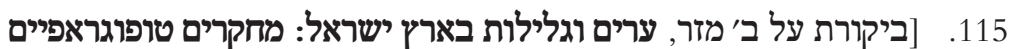

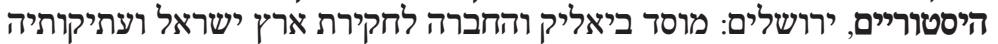
(תשל"ו)] שנתון, ב (תשל"וּ) 256-258 בירוים

115א. מבוא משוא

בתוך: מאיר פלס, משלי: ערוכים לפי נושאיו, תל-אביב: מ. ניומן (תשל״ט)

[ב]-[א]

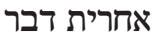

בתוך: מאיר רוטנברג, כללי תחביר נעלמים של לשון המקרא, תל-אביב: רשפים (תשל"ט) 185-188

F. Crüsemann, Der Widerstand gegen das Königtum, ביקורת על 117.

[Neukirchen-Vluyn: Neukirchener Verlag (1978)

קרית ספר, נד/ג (תש״״) 567-573

השוו 98* ספרית

118. [ [ביקורת על ז' משל, כונתילת עג'רוד: אתר מקודש מתקופת המלוכה בגבול ירול סיני, (קטלוג מס' 175), ירושלים: מוזיאון ישראל (תשל משרח)]

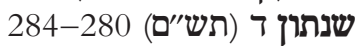

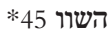

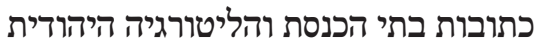
.119

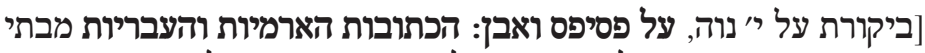

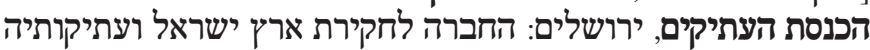




$$
\text { שנתוך, די"ח) }
$$

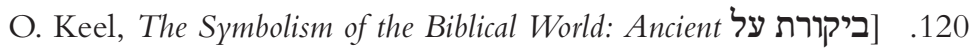

Near Eastern Iconography and the Book of Psalms, New York:

[Seabury (1978)

שנתוך, ה-ר (תשמ"א-תשמ"ב) 251-254

לשאלת ברכות השחר במגילות קומראן

[תגובה לר׳ ברודי, 'ברכות השחר בקות בומראץ??

[494-493

תרביץ, נא/ג (תשמ"ב) 495-496

53 ראו

122.

[Tübingen: Mohr-Siebeck (1977)

277 שנתרן, ז-ח (תשמ"ג-תשמ"ד

H. D. Hoffman, Reform und Reformen, Zürich: ביקורת על]

Theologischer (1980); H. Spieckermann, Juda unter Assur in [der Sargonidenzeit, Göttingen: Vandenhoeck \& Ruprecht (1982)

שנתוך, ט (תשמ"ה) 236-238

על הברית במקרא

E. W. Nicholson, God and His People: Covenant and ביקורת על במרית (1926]

[Theology in the Old Testament, Oxford: Clarendon (1986) קרית ספר, סא/ג (תשמ"ו-תשמ"ז) 573-576 (1026)

השוו 102*

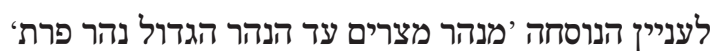

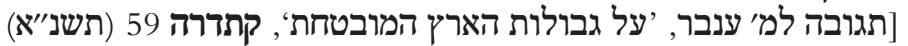

[189-188

קתדרה, 59 (תשנ"א) 189-190

85 ראורות

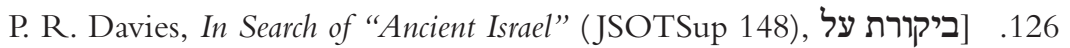

[Sheffield: Sheffield Academic Press (1992) 356 שנתוך, יא (תשנ"ז)

D. Pardee, 'Troisième reassemblage de RS 1.109,' Syria תגובה על 195] [1988) 191-173 355 שנתוך, יא (תשנ"1)

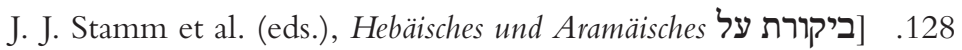
Lexicon zum Alten Testament von Ludwig Koehler und Walter Baumgartner,

[IV, Leiden: Brill (1990) שנתוך, יא (תשנ"ז) 351-354 
129. [ [ביקורת על ש' אחיטוב, אסופת כתובות עבריות: מימי בית ראשון וראשית

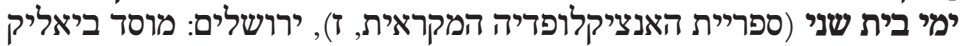
והחברה לחקירת ארץ ישראל ועתיקותיה (תשנ"ג)

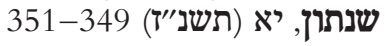

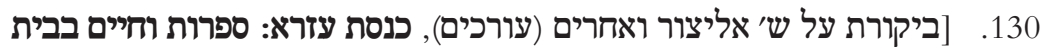
הכנסת, אסופת מחקרים מוגשת לעזרא פליישר, ירושלים: מכון בן צפרים וחים בבית (תשניה)

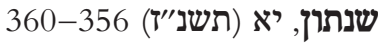

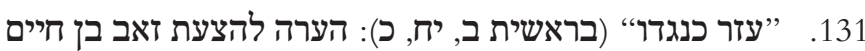

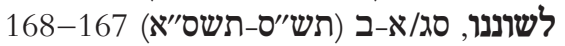

\section{ה. ערכים אנציקלופדיים}

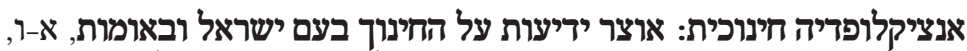

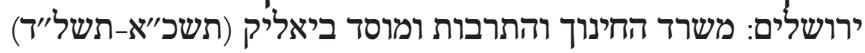
132. [ [שיתוף עם ש' טלמון] ד

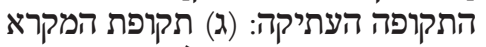
(עד המאה החמישית לפה"ס), [2]-[7"] המראת

אנציקלופדיה מקראית: אוצר הידיעות על המקרא ותקופתו, א-ט, ירושלים: מוסד

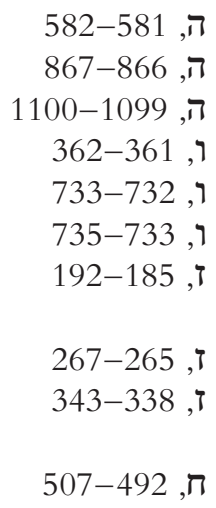

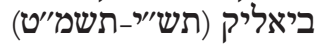

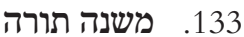

134. נכר, נכרי, נכריה

135. ספר התורה נכרי, נכרי

136. ערב, ערב רב

137. ציצת עיבת

138.

139. 138. 140 1ליה

140. קריאת התורה: (א) שורשי הקריאה

בתורה בתקופת המקרא

141. רות, מגילת רות בתות

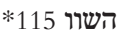

תורה, מחקר התורה בעת החדשה

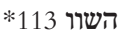

\section{ו. רשימת הקיצורים}

מחקרים בידיעת הארץ ועתיקותיה, ירושלים

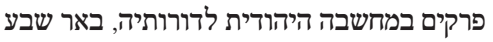
כתב עת של החברה לחקר המקרא בישראל, ירושלים

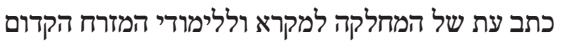
באוניברסיטת בן גוריון בנגב, באר שבע ולימדי
ארץ ישראל אשל באר שבע ישראל בית מקרא באר שבע מקוא 


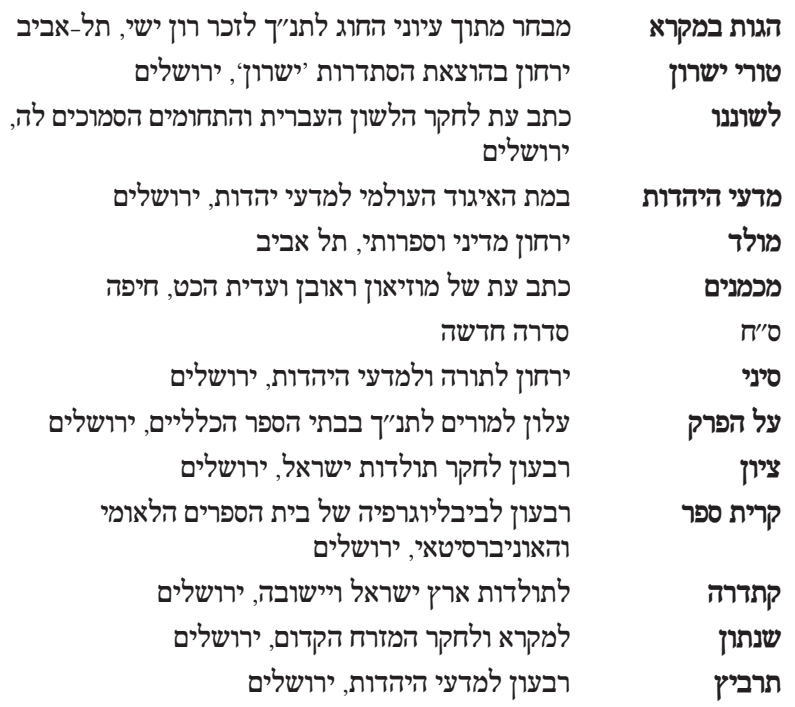

\section{Subject Index to the Bibliography}

Ancient Near Eastern documents: 6, 7, 39-40, 45, 50-52, 55-56, 60-61, 63-64, 73, 76-77, $79,86,89,94,96-97,105,120,127,129 ; * 13-* 14, * 22, * 25-* 26, * 28, * 35, * 37, * 40$, $* 47-* 48, * 56, * 65, * 67, * 71, * 74, * 76, * 85$

Biblical historiography: $4,24,29,72,96,103,123,141 ; * 16, * 34, * 53-* 54, * 75, * 98, * 110$, *115

Biblical theology: $23,30,51-52,58,75,88,101,106,138 ; * 39-* 40, * 49, * 79, * 82-* 83$, *89, $* 106, * 114, * 199, * 121$

Covenant: $\quad 6,33-35,39-40,69,108,113,124 ; * 4, * 14, * 18, * 20, * 25, * 36, * 55, * 60, * 74$, $* 95, * 100, * 102, * 106-* 107, * 117-* 118$

Cult and liturgy: $12 \mathrm{k}, 32,37,41,53,75,79,83,87,91-93,97,102,105,107,118-119,121$, $130 ; * 8, * 13, * 19, * 29, * 37, * 45, * 49, * 57, * 69, * 72, * 76-* 77, * 81, * 90, * 96-* 97, * 104$, $* 111, * 116, * 119-* 120$

Deuteronomy: $1-3,17-19,22,25,109,112,133 ; * 1, * 5, * 12-* 15, * 46, * 78, * 94, * 101, * 108$ Genesis: $\quad 8,27,47,73,99,131 ; * 28, * 33, * 48, * 59$

Idioms and expressions: $33,35,48,56,68,70,104,106,108,113,116,119,128-129,131$, $134,136-139 ; * 22, * 36, * 67, * 70, * 88, * 117-* 118$

Introduction to the Bible and history of interpretation: $5,28,46,57,59,67,71,82,95,98,110$, $126,132,142 ; * 3, * 9, * 23, * 30, * 32, * 51, * 82, * 121$

Israel, land of: $11,26,29,74,81,84-85,99,111,115,125 ; * 6, * 16, * 41, * 58-* 59, * 73, * 75$, $* 91$

Jerusalem as a political and religious capital: $90 ; * 44, * 80, * 86, * 101$

Justice, law, and legal institutions: $10,21,34,44,48-49,94 ; * 2, * 7, * 21, * 27, * 38, * 47, * 63$, $* 70, * 105, * 109, * 112$

New Testament: *29, *61, *84

Pentateuch and its law codes: $\quad 30,47,57,59,80,135,140,142 ; * 3, * 9, * 17, * 33, * 43$, *92-*93, $* 100, * 103, * 113$

Prophetic literature: $9,20,27,31,36,55,62,66,100 ; * 24, * 26, * 50, * 52$

Psalmodic literature: $38,50,76,77,120 ; * 35$

Qumran scrolls: $41,43,53-54,65,73,87-88,92-93,107,121-122 ; * 4, * 8, * 31, * 42, * 48$, $* 57, * 66, * 69, * 72, * 77, * 87-* 87 \mathrm{a}, * 90, * 99$

Ten Commandments and recitation of the Shema': $12,42,78 ; * 62, * 64, * 68$ 